\title{
Arctium tomentosum (Asteraceae): A new report of a native genus in the flora of Mongolia
}

\author{
Chuluunbat JAVZANDOLGOR ${ }^{1,2}$, Shukherdorj BAASANMUNKH ${ }^{3}$, Zagarjav TSEGMED ${ }^{1}$, \\ Batlai OYUNTSETSEG ${ }^{4}$, Vanjil GUNDEGMAA ${ }^{5}$ and Hyeok Jae $\mathrm{CHOI}^{3 *}$ \\ ${ }^{1}$ Laboratory of Plant Systematic and Phylogeny, Botanic Garden and Research Institute, \\ Mongolian Academy of Sciences, Ulaanbaatar 13330, Mongolia \\ ${ }^{2}$ State Key Laboratory of Systematic and Evolutionary Botany, Institute of Botany, Chinese Academy of Science, Beijing 100093, China \\ ${ }^{3}$ Department of Biology and Chemistry, Changwon National University, Changwon 51140, Korea \\ ${ }^{4}$ Department of Biology, School of Arts and Sciences, National University of Mongolia, Ulaanbaatar 14201, Mongolia \\ ${ }^{5}$ Department of Biology, School of Mathematics and Natural Sciences, Mongolian State University of Education, Ulaanbaatar 210648, Mongolia
}

(Received 15 November 2021; Revised 20 December 2021; Accepted 22 December 2021)

\begin{abstract}
Arctium tomentosum Mill. (Asteraceae), from Ulaanbaatar in the Khentei phytogeographical region of Mongolia, is recognized here as a new genus and species of the flora of Mongolia. Arctium differs from other genera of Asteraceae by the hooked apex of the involucral bracts. While A. tomentosum is most similar to $A$. lappa, it is easily distinguished by the glandular hairs of the corolla limb and the widened inner involucral bracts. Taxonomic notes, a description of the morphology, detailed photos, habitat information, the phenology and a distribution map of $A$. tomentosum are provided.
\end{abstract}

Keywords: Arctium tomentosum, flora of Mongolia, new record, vascular plants

To date, approximately 3,200 taxa belonging to 682 genera and 112 families of vascular plants have been recognized in Mongolia (Urgamal et al., 2014; Bazarragchaa et al., 2019; Shiga et al., 2020; Baasanmunkh et al., 2020, 2021a; Yano et al., 2021). The Asteraceae, with approximately 480 taxa belonging to 83 genera, are one of the biggest families in the country (Dariimaa 2014; Urgamal et al., 2014; Pyak et al., 2020). Furthermore, this family contains 21 endemic taxa $(20 \%$ of total endemic taxa) in Mongolia (Baasanmunkh et al., 2021b). The genus Arctium L., however, has not been recorded in the Mongolian flora (Dariimaa, 2014; Urgamal et al., 2014).

Arctium L. is a genus of ca. 11 to 12 species. Its native range includes Macaronesia, Africa, temperate Europe, and peninsula Malaysia (Duistermaat, 1996; López-Vinyallonga et al., 2011; Plants of the World Online, 2021). The species of Arctium are biennials or perennials. The hooked apex of the involucral bracts is the most distinguishable characteristic that separates it from other genera of Asteraceae (Duistermaat, 1996). Among Arctium, A. tomentosum Mill. is native to temperate Eurasia
(Kaplan et al., 2019; Plants of the World Online, 2021). It has also been introduced to the British Isles, Spain, Norway, and North America (Duistermmat, 1996; Kaplan et al., 2010; Plants of the World Online, 2021). The native status, however, is questionable in the countries of central and northern Europe (Kaplan et al., 2010). While, Arctium lappa L., the most similar species to A. tomentosum, is also distributed in temperate Eurasia (Duistermmat, 1996; Plants of the World Online, 2021) and introduced in Japan and South Korea (Plants of the World Online, 2021). During our field surveys, we found $A$. tomentosum from two locations in Mongolia.

\section{Materials and Methods}

The field surveys were conducted in the Khentei region of Mongolia in 2021. Detailed photographs were taken during the field surveys by C. Javzandolgor. Herbarium specimens were deposited in Botanic Garden and Research Institute, Mongolian Academy of Sciences (UBA) and Department of Biology,

*Author for correspondence: hjchoi1975@changwon.ac.kr 

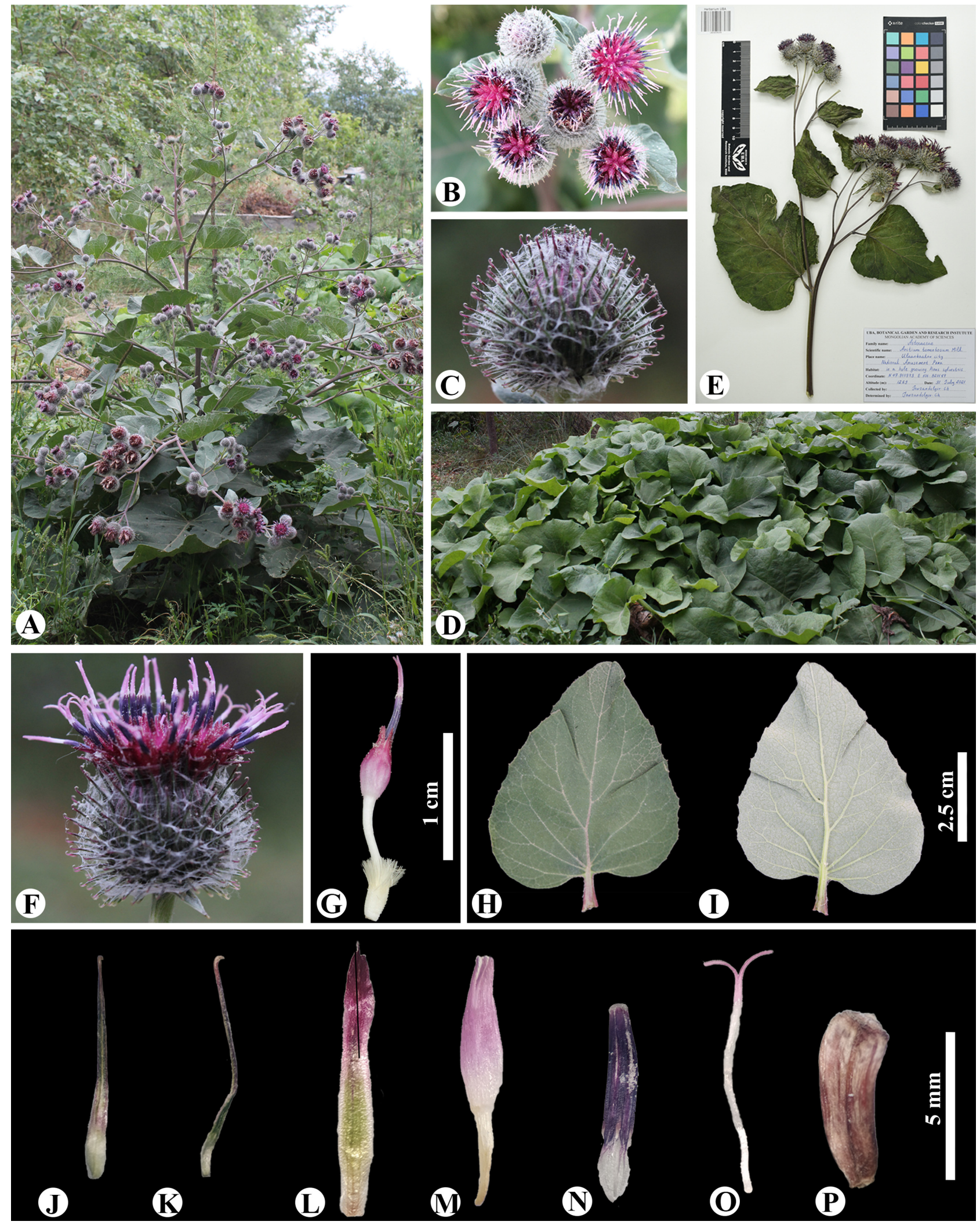

Fig. 1. Photographs of Arctium tomentosum in Mongolia. A. Habit. B. Synflorescence. C. Involucral bract. D. Basal leaves. E. Herbarium specimens. F. flowers (front). G. Flower. H. Leaf (adaxial surface). I. Leaf (abaxial surface). J. Middle involucral bract (dorsal view). K. Middle involucral bract (lateral view). L. Inner involucral bract (dorsal view). M. Corolla. N. Anther. O. Apical part of style. P. Achene. 
National University of Mongolia (UBU) (Thiers, 2020). The grid distribution map was created in ArcGis, using the same approach as Baasanmunkh et al. (2021a).

\section{Results and Discussion}

During our field surveys, we found Arctium tomentosum Mill., a new genus to the flora of Mongolia at two locations in Mongolia. Arctium tomentosum is most similar to A. lappa but according to the taxonomic key of Duistermaat (1996), it is easily distinguished by the glandular hairs of the corolla limb and widened inner involucral bracts. However, recent studies have suggested that the mitochondrial and chloroplast genome sequences in both species are almost similar (Xing et al., 2019; Zhang et al., 2020). In Mongolia, A. tomentosum occurs in forest fringes, field margins, fallow fields, dump sites and in towns and villages. Both species are used as medicinal plants in China (Xing et al., 2019), but the current source of medicinal or food is lacking due to not being recorded in Mongolia. We provide a taxonomic description below based on our fresh collections, detailed photographs (Fig. 1), and a distribution map (Fig. 2).

\section{Taxonomic Treatment}

Arctium tomentosum Mill., Gard. Dict. ed 8, no. 3, 1768 (Figs. 1, 2).--Neotype: According to Duistermaat (1996) and
López-Vinyallonga et al. (2011). Herb. Linnaeus 964.1 (LINN; Isoneotypes: BM, photo!); Lappa tomentosa (Mill.) Lam., Fl. Franç. 2: 37, 1779.

Herbs, biennial, stem erect, branched, 130-160 cm tall, glabrous. Leaves abaxially grayish-white and densely felted, adaxially green and glabrous; petioles $8-12 \mathrm{~cm}$ long. Basal leaves: blade heart-shaped, 30-35 × 25-30 cm, margin sparsely denticulate, apex obtuse. Cauline leaves similar to basal leaves. Synflorescence corymbose, with many capitula. Capitula solitary, with more than 40 flowers, arachnoid hairy. Involucral bracts in 10-14 rows, herbaceous, distally often tinged red. Outer phyllaries subulate, triangular-subulate or lanceolate, middle phyllaries linear-triangular all with a hooked apex; inner phyllaries obovate to linear-obovate, apex truncate, acuminate, straight or slightly curved. Corolla $8-12 \mathrm{~mm}$ long, white, (wine) red, or (pale) reddish-purple, tube 4-6 mm long. Stamens: filaments $2.4-4 \mathrm{~mm}$ long, verrucate, anthers 3.8-5.4 $\times 0.3-0.5 \mathrm{~mm}$, (dark) blue (or purple). Stylar apex 2.5-3.9 mm long, pink. Achenes 5-8 mm long, oblongoid, pale brown variegated with dark brown, multistriate. Pappus bristles pale brown, ca 4-6 $\mathrm{mm}$.

Flowering and fruiting: June to September.

Distribution: Temperate Eurasia (Duistermmat, 1996; Plants of the World Online, 2021), Mongolia (Khentei region), as well as introduced in British Isles, Spain, Norway, and North America (Duistermmat, 1996).

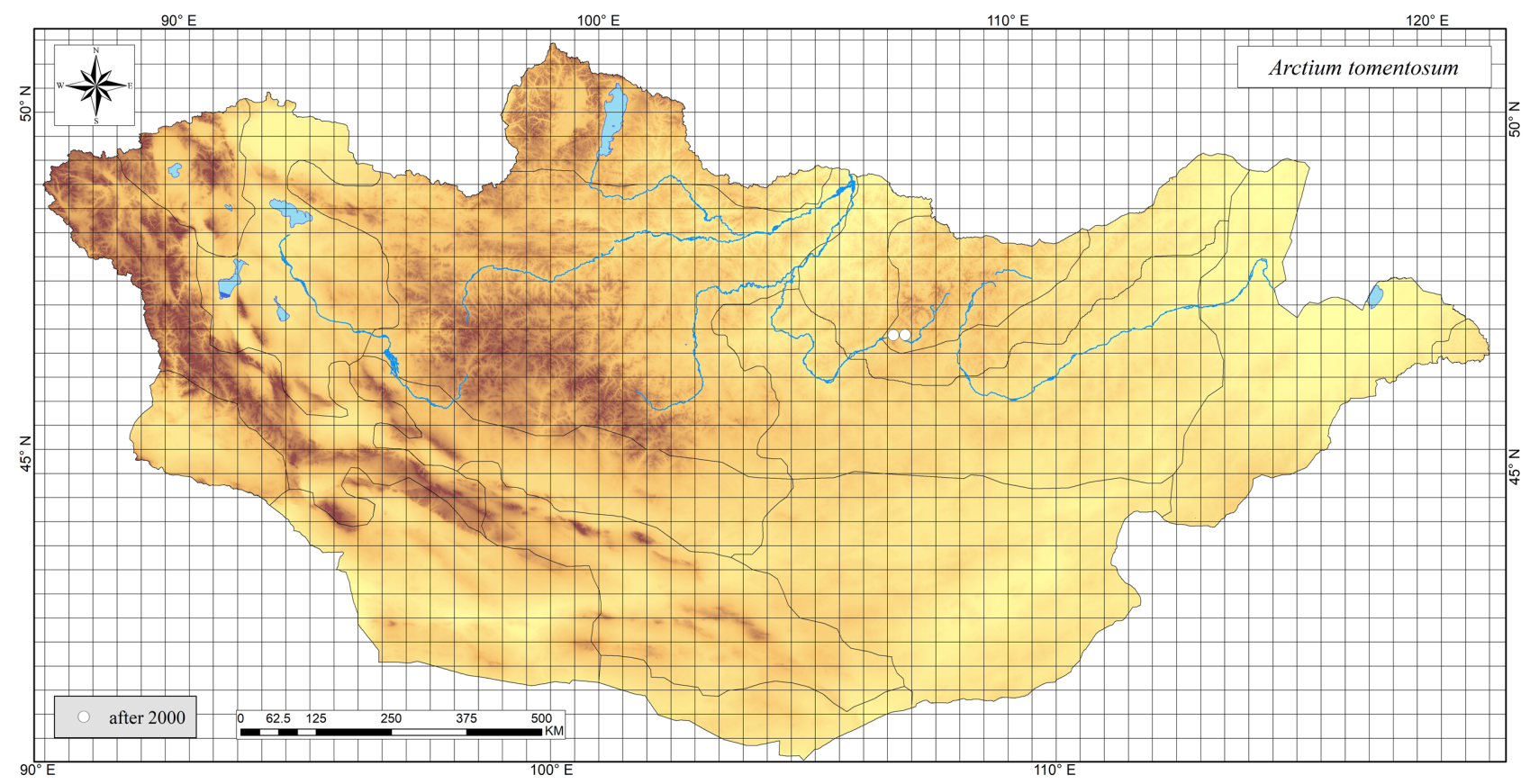

Fig. 2. Distribution map of Arctium tomentosum in the Khentei region of Mongolia. 
Specimens examined: MONGOLIA. Khentei region: Ulaanbaatar, National Amusement Park, 31 Jul 2021, 47 ${ }^{\circ} 91^{\prime} 03.7^{\prime \prime N}, 106^{\circ} 92^{\prime} 01.8^{\prime \prime E}$; 1,289 m a.s.1., C. Javzandolgor 2021073101 (UBA). Ulaanbaatar, Sukhbaatar district, 47 $97^{\prime} 49.3^{\prime \prime N}, 106^{\circ} 92^{\prime} 80.21 " \mathrm{E} ; 1,289$ m a.s.1., 5 Aug 2021, C. Javzandolgor 2021080502 (UBA).

ORCID: Chuluunbat JAVZANDOLGOR https://orcid.org/ 0000-0003-1158-3291; Shukherdorj BAASANMUNKH https:/ /orcid.org/0000-0003-4224-9376; Zagarjav TSEGMED https:// orcid.org/0000-0002-6024-4918; Batlai OYUNTSETSEG https:/ /orcid.org/0000-0003-3772-3301; Vanjil GUNDEGMAA https:/ /orcid.org/0000-0001-9883-2451; Hyeok Jae CHOI https:// orcid.org/0000-0001-6315-0071

\section{Acknowledgments}

This study was supported by a research project (A survey on the vascular flora of Mongolia; Grant Number KNA 1-2-38, 20 5) of the Korean National Arboretum, South Korea, and partly supported by the National University of Mongolia's Seed Grant. We thank Mr. E. Choijilsuren, who found the first locations of this species in Mongolia, for providing valuable information. The authors are grateful to two anonymous reviewers and David Boufford (Harvard University Herbaria) for their critical reading of the manuscript with valuable comments.

\section{Conflicts of Interest}

The authors declare that there are no conflicts of interest.

\section{Literature Cited}

Baasanmunkh, S., N. Nyamgerel, G.-A. Bayarmaa, B. Oyuntsetseg, K. Oyundelger and H. J. Choi. 2020. A new record of critically endangered Saussurea bogedaensis (Asteraceae) from Dzungarian Gobi, Mongolia. PhytoKeys 160: 109-121.

Baasanmunkh, S., B. Oyuntsetseg, P. Efimov, Z. Tsegmed, S. Vandandorj, K. Oyundelger, M. Urgamal, A. Undruul, K. Khaliunaa, T. Namuulin and H. J. Choi. 2021a. Orchids of Mongolia: Taxonomy, species richness, and conservation status. Diversity 13: 302.

Baasanmunkh, S., M. Urgamal, B. Oyuntsetseg, A. GrabovskayaBorodina, K. Oyundelger, Z. Tsegmed, V. Gundegmaa, A. A. Kechaykin, A. I. Pyak, L. Q. Zhao and H. J. Choi. 2021 b. Updated checklist of vascular plants endemic to Mongolia. Diversity 13: 619.

Bazarragchaa, B., G. Batdelger, D. Shagdar, W. K. Paek and J. Lee.
2019. Scutellaria krasevii Kom. \& I. Schischk. ex Juz. (Lamiaceae): A new record species from Mongolia. Korean Journal of Plant Taxonomy 49: 198-201.

Dariimaa, S. 2014. Flora of Mongolia, Vol. 14a. Bembi San Printing, Ulaanbaatar, 277 pp. (in Mongolian)

Duistermaat, H. 1996. Monograph of Arctium L. (Asteraceae): Generic delimitation (including Cousinia Cass, p.p.), revision of the species, pollen morphology, and hybrids. Gorteria Supplement 3: 1-143.

Kaplan, Z., J. Danihelka, J. Chrtek, J. Zázvorka, P. Koutecký, L. Ekrt, R. Řepka, J. Štěpánková, B. Jelínek, V. Grulich, J. Prančl and J. Wild. 2019. Distributions of vascular plants in the Czech Republic. Part 8. Preslia 91: 257-368.

López-Vinyallonga, S., K. Romaschenko, A. Susanna and N. Garcia-Jacas. 2011. Systematics of the Arctioid group: Disentangling Arctium and Cousinia (Cardueae, Carduinae). Taxon 60: 539-554.

Plants of the World Online. 2021. Facilitated by the Royal Botanic Gardens, Kew. Published on the Internet. Retrieved Aug. 10, 2021, available from http://www.plantsoftheworldonline.org/.

Pyak, E. A., A. I. Pyak and V. V. Madyka. 2020. Saussurea odorata (Asteraceae), a new species from western Mongolia. Phytotaxa 470: 235-242.

Shiga, T., K. Khaliunaa, S. Baasanmunkh, B. Oyuntsetseg, S. Midorkawa and H. J. Choi. 2020. New Mongolian records of two genera, seven species, and two hybrid nothospecies from Khar-Us Lake and its associated wetlands. Journal of AsiaPacific Biodiversity 13: 443-453.

Thiers, B. 2020 [Continuously updated]. Index Herbariorum. A global directory of public herbaria and associated staff. New York Botanical Garden's Virtual Herbarium. Retrieved Jun. 1, 2021, available from http://sweetgum.nybg.org/ih/.

Urgamal, M., B. Oyuntsetseg, D. Nyambayar and C. Dulamsuren. 2014. Conspectus of the Vascular Plants of Mongolia. Admon Printing, Ulaanbaatar, $333 \mathrm{pp}$.

Xing, Y.-P., L. Xu, S.-Y. Chen, Y.-M. Liang, J.-H. Wang, C.-S. Liu, T. Liu and T.-G. Kang. 2019. Comparative analysis of complete chloroplast genomes sequences of Arctium lappa and A. tomentosum. Biologia Plantarum 63: 565-574.

Yano, O., T. Shiga, K. Khaliunaa, S. Baasanmunkh, B. Oyuntsetseg and H. J. Choi. 2021. A new record of Carex capricornis (Cyperaceae) from Mongolia. Journal of Japanese Botany 96: 238-241.

Zhang, D., Y. Xing, L. Xu, R. Zhao, Y. Yang, T. Zhang, S. Li, G. Bao, W. Ao, T. Liu and T. Kang. 2020. Comparative analysis of the mitochondrial genome sequences of two medicinal plants: Arctium lappa and A. tomentosum. Research Square Preprint at https://doi.org/10.21203/rs.3.rs-28443/v1. 